\title{
SWITCHING COSTS IN NETHERLANDS ENERGY MARKETS: CAN LIBERALISATION BRING BENEFITS TO SMALL CUSTOMERS?**
}

BY

\author{
MARC POMP* AND VICTORIA SHESTALOVA*
}

\begin{abstract}
Summary
We use data from a consumer survey to uncover factors deterring consumer switching in liberalised residential energy markets in The Netherlands. We find that actual or perceived switching costs represent an important barrier for switching energy suppliers. This enables incumbent firms to charge higher markups than entrants. We analyse the welfare consequences of switching costs in two scenarios, a pessimistic one in which switching costs remain at the level measured in the survey and an optimistic one in which they decline enough for the market to reach a competitive equilibrium level. The paper concludes with a discussion of policy options for reducing switching costs.
\end{abstract}

Key words: consumer choice, energy, switching cost, competition policy

\section{INTRODUCTION}

The theory of industrial organisation has long focused on the behaviour of firms in explaining high markups. However, it is increasingly recognised that consumer behaviour may also be important. In a pioneering paper, Waterson (2003) provides numerous examples in which a lack of consumer response to market signals results in insufficient competition. The presence of search and switching costs is one important reason why consumers do not always switch in response to a substantial difference in price. Search and switching costs may consist of monetary costs (e.g. switching fees), but may also include costs in terms of time, dislike of paper-work, stress, etc. (see e.g. Klemperer 1995). Measuring these factors and estimating their consequences for market outcomes is hard, but also of crucial importance for policy design, especially in newly liberalised markets such as markets for energy where consumers previously had no choice of supplier. In this paper, we attempt to shed light on the

\footnotetext{
* The Netherlands Bureau for Economic Policy Analysis (CPB), P. O. Box 80510, The Hague, 2508 GM, The Netherlands. Corresponding author: e-mail: j.m.pomp@cpb.nl

** We are grateful to the Dutch Consumer Union for providing the data for this analysis. We also would like to thank two anonymous referees and the editor for their comments and helpful suggestions.
} 
importance of switching costs for the success or failure of the liberalisation of the residential segment of the Dutch retail energy market. This liberalisation took effect on July 1, 2004, and completed the move to liberalised retail energy markets that began in 2000 .

We provide new empirical evidence on search and switching costs of Dutch consumers in energy markets, based on data from a consumer survey of the Dutch Consumer Union (Consumentenbond). The study is intended to inform policy makers and regulators about the role of search and switching costs in determining the effects of liberalisation in terms of market outcomes and ultimately welfare. We argue that it is important to reduce real and perceived switching costs. We discuss policy options aimed at that, such as introduction of standard contracts and improvement of consumer information about actual switching costs.

The paper proceeds as follows. We describe Dutch residential energy markets in section 2. Next, we present empirical evidence from a consumer survey (section 3), after which we turn to welfare implications of switching costs (section 4). Section 5 discusses policy options to reduce switching costs. Section 6 concludes.

\section{MARKET STRUCTURE AND ENTRY}

The liberalisation of Dutch energy markets began with the liberalisation of the large user segment in 1999. As a next step, the middle user segment was opened up to competition in 2002. Finally, the small user segment followed in 2004. As a parallel development, green electricity ${ }^{1}$ markets were fully liberalised on July 1, 2001, creating possibilities for entry in the middle and small user segments of the energy markets. Before the completion of liberalisation in $2004,48 \%$ of households had switched to green electricity, and one quarter of them had switched to another supplier. ${ }^{2}$ On July 1, 2004, the market was fully liberalised and all consumers were allowed to choose their supplier(s) of green or grey electricity ${ }^{3}$ and gas.

Prior to liberalisation there were about 20 regional energy companies, some of which merged between 2000 and 2004. These regional companies were vertically integrated public monopolies. In the course of restructuring, network firms were separated from production and retail supply firms. ${ }^{4}$ These

1 Green energy is defined as energy generated from renewable resources through licensable and environmentally and socially responsible production processes.

2 According to the Consumentenbond (2004). Their estimate of the number of green electricity consumers is close to the reports of the branch organisation of energy companies.

3 Electricity that is not classified as 'green', is called 'grey'.

4 Traditionally, energy suppliers belonged to vertically integrated regional energy holdings owned by provincial governments or municipal councils. In the course of the industry restructuring, the firms were separated functionally and legally. The Dutch Minister of Economic 
competitive parts are now fully liberalised and can compete internationally ${ }^{5}$, while the networks remain regulated by the Dutch energy regulator, DTe.

Supply firms represent the commercial link of the energy industry with the customer: they sell energy, take care of metering and collect payments. In addition to traditional suppliers, there are new firms in the Dutch energy markets.

Table 1 (second column) shows the initial market shares of the incumbent electricity suppliers in the residential segment, based on historic data. The three largest suppliers served more than $90 \%$ of households, while several small companies supplied the rest.

Post-liberalisation data on market shares is not publicly available, but it is known from the press and from published reports that incumbents were losing market share to entrants. Less than a year after liberalisation, the combined market share of the two largest entrants in the residential electricity market, Oxxio and Greenchoice, already amounted to $8 \%{ }^{6}$ According to DTe (2006), there are currently 23 electricity suppliers and 19 gas suppliers in this segment of the energy market; the market share of the three largest companies is $82 \%$ in electricity and in $79 \%$ in gas.

The last column of Table 1 shows market shares of the electricity companies in our dataset. This dataset was collected by the Dutch Consumer Union in September 2004. It represents the situation among members of the Consumer Union. Of all respondents, $82 \%$ were served by the three largest incumbents, the same percentage as in DTe (2006), and $9.3 \%$ by new entrants. Relatively many respondents who switched to new entrants have chosen Oxxio or Greenchoice.

Note that most Dutch consumers were well aware that they could change supplier as of July 2004. First, green electricity markets had been fully liberalised for 3 years, so the liberalisation idea was not completely new for them. Also, the final step towards full liberalisation was preceded by a massive publicity campaign by both the Ministry of Economic Affairs and incumbent

Footnote 4 continued

Affairs intends to implement their ownership separation. See Mulder and Shestalova (2006) for more detail on ownership separation issues.

5 The Netherlands is a net importer of electricity (net import is about $16 \%$ of consumption) and a net exporter of gas (net export is about one third of production). Suppliers buy energy from producers and sell it to consumers of electricity. Producers can also be suppliers. Most electricity produced and consumed in The Netherlands is thermal. The share of green electricity has been increasing over the last few years. In 2005, the share of green electricity in import was $8.6 \%$ and the share of domestically produced green electricity in the total electricity consumption was 6.1\%. Sources: TenneT (2006), CBS (2005), Energiened (2002).

6 In 2005, Oxxio had $0.5 \mathrm{mln}$ connections and Greenchoice had above $0.1 \mathrm{mln}$ connections. Source: Energiea, April 6, 2005, www.energiea.nl 


\section{TABLE 1 - MARKET SHARES IN THE ELECTRICITY MARKET FOR SMALL RESIDENTIAL CUSTOMERS}

\begin{tabular}{lll}
\hline & $\begin{array}{l}\text { Market share before liber- } \\
\text { alisation (based on historic } \\
\text { data in 2000, incorporating } \\
\text { mergers among incum- } \\
\text { bents) }\end{array}$ & $\begin{array}{l}\text { Distribution of consumers } \\
\text { in the Consumer Union } \\
\text { survey of September 2004 }\end{array}$ \\
& $\%$ & \\
& & \\
& 38.5 & 31.1 \\
Nuon companies & 24.6 & $21.8^{\mathrm{a}}$ \\
Eneco companies & 33.1 & 29.5 \\
Essent companies & 93.1 & 82.4 \\
The large three together & 0.7 & 1.1 \\
Cogas & 2.7 & 2.9 \\
Delta & 1.4 & 1.7 \\
NRE & 0.6 & 0.3 \\
InfraMosane & 0.5 & $1.1^{\mathrm{b}}$ \\
ONS & 0.4 & 0.3 \\
RENDO & 0.6 & 0.5 \\
Westland & 6.9 & 7.9 \\
Smaller incumbents together & & 4 \\
Oxxic & & 0.2 \\
Electrabel & & 0.7 \\
Energiedirect & 3 \\
Greenchoice & & 0.5 \\
Intergas & & 0.4 \\
Obragas & & 0.5 \\
Other entrants & & 9.3 \\
Entrants together & & \\
\hline
\end{tabular}

Notes: Market shares are derived as the ratio of small customers of each company to the total number of small customers in The Netherlands (column 2) and in the survey (column 3).

a Eneco and Shell Nederland.

$\mathrm{b}$ ONS and Echte Energie.

${ }^{c}$ Energiebedrijf.com, Durion and Evolta, now under the name Oxxio.

Source: Own computations based on data on distribution companies from DTe decisions on $\mathrm{X}$-factors and from the consumer survey of the Dutch Consumer Union.

companies. ${ }^{7}$ Given this, the consumer awareness regarding the possibility to change energy supplier was very high in The Netherlands (for example, almost $100 \%$ of consumers involved in this consumer survey were aware about this possibility). Many Dutch consumers arrange switching on the web. Access to internet in The Netherlands is relatively high, for example, in 2004 (the year of the completion of liberalisation), nearly $60 \%$ of the Dutch pop-

7 In addition to advertising, some companies offered presents and discounts to new customers to increase their willingness to switch. 
ulation had access to the Internet at home. ${ }^{8}$ This is quite different from the situation prevailing on the eve of liberalisation in the UK, where both awareness was not very high (partly because of regional differences in liberalization dates, see Giulietti et al. 2005) and the level of the internet access was much lower.

\section{EVIDENCE ON SWITCHING COSTS}

In this section we use data from a consumer survey conducted by the Dutch Consumer Union to gain insights in perceived search and switching costs in energy markets. The survey was conducted 3 months after liberalisation, in September 2004. A total of 1,123 members of the consumer panel of the Consumer Union took part in the survey (out of 1,800 panel members to whom it was sent, i.e., a response rate of $62 \%$ ). The survey included questions about consumer behaviour in energy markets, attitude towards liberalisation, views about the role of institutions, etc. Most questions in the survey were multiplechoice questions. For example, respondents had to indicate to what degree they agreed or disagreed with a certain statement. In addition, there were 'factual' questions, concerning switching behaviour, the type of contract, the amount of the electricity bill, etc. It was possible to link this information to characteristics of respondents, such as age, education, income category and home ownership.

Before we present relevant outcomes from the survey, a remark should be made regarding the representativeness of our sample. The composition of the respondents in our dataset is not fully representative for the Dutch population. The members of the consumer panel are on average somewhat older, and have a higher level of income and education than the average in The Netherlands. ${ }^{9}$ Especially large is the discrepancy in home ownership: $80 \%$ of our sample are home-owners, while according to the latest data of the Central Bureau of Statistics, the percentage for The Netherlands as a whole is $52 \%$. Therefore, in the welfare analysis of the effects of switching costs in the next section we use post-stratified estimates correcting for this difference. ${ }^{10}$

As a background to the analysis that follows, Table 2 shows general attitudes of consumers towards liberalisation. Clearly, liberalisation was not met with enormous enthusiasm by these consumers: only slightly over one quarter more or less agreed with the thesis that liberalisation will favour consumers.

In this market, consumer search and switching costs relate to time and effort spent on searching and switching. Monetary switching costs may arise

8 Source: CBS (2005) About 30\% of adults do not use the Internet, Web magazine, 14 June 2005, www.cbs.nl.

9 Consumentenbond (2004).

10 See e.g. Rice (1995). 


\section{TABLE 2 - ANSWERS TO THE QUESTION: DO YOU AGREE THAT LIBERALISATION OF ENERGY MARKET WORKS IN FAVOUR OF CONSUMERS?}

Percentage (St. error)

$\begin{array}{lr}\text { Absolutely agree } & 2.9(0.5) \\ \text { Agree to some extent } & 23.2(1.3) \\ \text { Neither agree nor disagree } & 29.2(1.4) \\ \text { Disagree to some extent } & 19.2(1.2) \\ \text { Absolutely disagree } & 16.3(1.1) \\ \text { No opinion/not applicable } & 9.1(0.9) \\ \text { Total number of observations } & 1,097\end{array}$

TABLE 3 - ANSWERS TO THE QUESTION: HOW MUCH TIME YOU THINK WOULD BE NEEDED TO FIND A NEW SUPPLIER AND TO SIGN UP THERE?

\begin{tabular}{lccr}
\hline & Switchers & Non-switchers & \multicolumn{1}{l}{ Total } \\
& & & \\
\hline Not more than 1 hour & $17.3(3.1)$ & $7.5(0.9)$ & $9.0(0.9)$ \\
Some hours & $30.7(3.8)$ & $18.5(1.3)$ & $20.4(1.2)$ \\
A morning or an afternoon & $15.3(3.0)$ & $22.5(1.4)$ & $21.3(1.2)$ \\
A day & $14.7(2.9)$ & $18.8(1.3)$ & $17.9(1.2)$ \\
Another answer, namely... & $6.0(1.9)$ & $4.0(0.7)$ & $4.3(0.6)$ \\
Indicated that the time needed ranges & $2.7(1.3)$ & $2.8(0.5)$ & $2.7(0.5)$ \\
from 'days' to 'weeks' & & & $24.4(1.3)$ \\
Don't know (more) & $13.3(2.8)$ & $26.0(01.5)$ & 1,099 \\
Total number of observations & 150 & 904 & \\
& & & \\
\hline
\end{tabular}

This table gives the respective percentages and their standard errors.

Not all respondents indicated whether they had switched supplier or not. Therefore, the number of switchers and non-switchers do not sum up to the total.

only in case of premature termination of a contract with a fixed duration (see section 5). Table 3 provides an overview of responses to a question about the expected time needed for searching and switching. Most respondents $(69 \%)$ expect to spend one day or less. When we split the observations into two groups consisting of those who switched provider ('switchers') and those who did not ('non-switchers'), we see that on average switchers have substantially lower estimates of the time needed than non-switchers. Here we define 'switching' as changing supplier for one or more energy products (green electricity, grey electricity or gas), which means that our definition includes also switches of green energy supplier made before July 2004. Note that the number observations in each subgroup is smaller than in the total sample, espe- 
cially in the subgroup of switchers, which is why the standard errors become larger.

There are two interpretations for this difference. Either the differences are real, and non-switchers indeed need more time to switch, or ex ante expectations of switchers and non-switchers were the same but switchers found out, by the very act of switching, that the time requirement was much less than they had expected. In the latter case, causality runs from switching to the expected time needed for switching. Put differently, expected time needed for switching is endogenous. If endogeneity does not play an important role, we would expect that expected switching costs are higher for low-educated and older people, for whom the time-costs of obtaining and processing information are plausibly higher. Hence, there will be relatively fewer switchers among them than in the total sample. However, this is not what we find in our data: the percentage of switchers in the complete sample $(14.4 \%$, st. error $1.1 \%)$ is roughly the same as in the ' $65+$ '-group $(15.6 \%$, st. error $2.7 \%)$, and in the group with education not higher than intermediate vocational (MBO; 14.5\%, st. error $1.7 \%$ ).

We therefore conclude tentatively that expected time needed for switching is likely to be endogenous, i.e. that the difference between switchers and non-switchers reflects a difference between ex ante expectation of perceived switching costs and actual switching costs.

Respondents were also asked what minimum amount of bill savings per year would induce them to switch supplier (see Table 4). Required bill savings are lower for switchers than for non-switchers: on average, about $60 \%$ of respondents would switch for bill savings less than 150 euros, however, among switchers the figure of $60 \%$ is reached already at bill savings of 100 euros. This implies that switchers are more responsive to price than non-switchers. They are more likely to use the opportunity to reduce their energy bill by switching supplier.

\section{CONSEQUENCES OF SWITCHING COSTS FOR PRICES AND WELFARE}

In this section, we study the consequences of switching costs for welfare effects of liberalisation. Following Giulietti et al. (2005), we first calculate the price differential between incumbent firms and new entrants given current switching preferences (as measured in the survey). Next, we construct two scenarios for the welfare effects of liberalisation: a pessimistic one based on current switching behaviour, and an optimistic one in which the willingness to switch at a given price differential sharply increases.

\subsection{Pricing by Incumbents}

If switching costs are substantial, incumbent firms may follow a strategy of 'milking' their existing customer base: charging prices well above those 
TABLE 4 - ANSWERS TO THE QUESTION: WHAT IS THE MINIMUM AMOUNT PER YEAR THAT YOU WOULD LIKE TO SAVE ON YOUR ENERGY EXPENSES TO WANT TO CHANGE SUPPLIER?

\begin{tabular}{lrrr}
\hline & Switchers & Non-switchers & \multicolumn{1}{l}{ Total } \\
\hline Less than 25 euros & & & \\
25-50 euros & $5.4(1.9)$ & $1.2(0.4)$ & $1.8(0.4)$ \\
$50-75$ euros & $25.1(3.6)$ & $8.9(0.9)$ & $11.1(0.9)$ \\
$75-100$ euros & $15.6(3.0)$ & $12.5(1.1)$ & $12.6(1.0)$ \\
100-150 euros & $14.3(2.9)$ & $15.5(1.2)$ & $15.4(1.1)$ \\
150-200 euros & $12.2(2.7)$ & $18.6(1.3)$ & $18.0(1.2)$ \\
200-250 euros & $2.0(1.2)$ & $5.0(0.7)$ & $4.6(0.6)$ \\
250-300 euros & $2.0(1.2)$ & $5.0(0.7)$ & $4.4(0.6)$ \\
More than 300 euros & $0.7(0.7)$ & $2.3(0.5)$ & $2.2(0.4)$ \\
Savings play no role in switching decision & $2.0(1.2)$ & $3.3(0.6)$ & $3.2(0.5)$ \\
Will never change, independently of the & $6.1(2.0)$ & $4.5(0.7)$ & $4.6(0.6)$ \\
amount to be saved & $4.1(1.6)$ & $6.7(0.8)$ & $6.2(0.7)$ \\
Do not know & $10.2(2.5)$ & $16.4(1.2)$ & $15.8(1.1)$ \\
Total number of observations & 147 & 907 & 1,099 \\
& & & \\
\hline
\end{tabular}

This table gives the respective percentages and their standard errors.

Not all respondents indicated whether they had switched supplier or not. Therefore, the number of switchers and non-switchers do not sum up to the total.

charged by new entrants. In order to determine how much higher, we start from the following equation for the variable profits of an incumbent firm:

$$
\Pi=\bar{Q} \cdot\left(P_{I}-C\right) \cdot N,
$$

where $\bar{Q}$ is the quantity of energy consumed, assumed to be independent of price, over the relevant price range; $P_{I}$ the price charged by an incumbent firm; $C$ the marginal cost and $N$ is the number of customers of an incumbent firm.

Consistent with what we find in our data, we will assume that switchers have an annual energy consumption equal to the average in the sample. ${ }^{11}$ Given this assumption, equation (1) implies the following decomposition of a change in profits:

$$
\Delta \Pi=\bar{Q} \cdot\left[N \Delta P_{I}+\left(P_{I}-C\right) \cdot \Delta N+\Delta P_{I} \Delta N\right] .
$$

11 In particular, the means of annual electricity and gas consumption of switchers are close to those in the total sample. The respective numbers (with standard errors given in brackets) are: $3,813(198) \mathrm{kWh}$ and $3,789(70) \mathrm{kWh}$ of electricity; and 1,993 (114) $\mathrm{m}^{3}$ and $1,828(35) \mathrm{m}^{3}$ of gas. 
Equation (2) can be rewritten as:

$$
\Delta \Pi=\bar{Q} \cdot(N+\Delta N) \cdot \Delta P_{I}+\bar{Q} \cdot\left(P_{I}-C\right) \cdot \Delta N .
$$

We will use this equation to analyse the effect of raising $P_{I}$ on profits, ceteris paribus. Since $P_{I}$ is the choice variable of the firm, we interpret $\Delta N$ as the change in the number of customers as a consequence of raising price. Under this interpretation, the first term in the RHS of equation (3) equals additional profits on remaining customers as a result of an increase in $P_{I}$, while the second term on the RHS equals forgone profits on customers who have switched to another firm as a result of an increase in $P_{I}$.

We do not directly observe the marginal cost $C$. However, we will assume that new entrants price at marginal cost, in which case we can use entrants' prices as an estimate of marginal costs. This assumption is theoretically reasonable: in competitive markets, equilibrium prices should be near marginal cost. Although in practice new entrants may temporarily price below marginal cost to gain market share, we ignore this possibility, as such a strategy cannot be feasible in the long run. Pricing above marginal costs is possible, but our results still hold as long as the entrants' price does not exceed marginal cost too much. ${ }^{12}$ With this assumption, equation (3) becomes:

$$
\Delta \Pi=\bar{Q} \cdot(N+\Delta N) \cdot \Delta P_{I}+\bar{Q} \cdot\left(P_{I}-P_{E}\right) \cdot \Delta N,
$$

where $P_{E}$ is the price of new entrants.

Equation (4) will be used to determine the profit maximising price of an incumbent firm. As indicated in section 3, our data contain information on the number of customers who would switch to another provider, $\Delta N$, for various amounts of bill savings, $\bar{Q} \cdot \Delta P_{I}$. Plugging these combinations of $\bar{Q} \cdot \Delta P_{I}$ and $\Delta N$ into equation (4) allows us to calculate the effects on profits of successive stepwise increases in price above the level of entrants. ${ }^{13}$

Table 5 below presents the results of this procedure. The table is based on a representative firm that initially (at $P_{I}=P_{E}$ ) has 1,000 customers. This number serves only as a normalisation and does not in any way affect our substantive results. The first row shows that, with a price differential between

12 If entrants price somewhat above marginal costs, the incumbent's loss from additional switchers is larger than in Table 5. However, as long as entrants' markups are small, the incumbent's profit will be still maximised at a price differential of at least 75 euros. Only if markups are substantial, the incumbent's profit is maximised at a smaller price differential. However, the incumbent's price is still higher in the latter case.

13 In reality, the distribution of bill savings required in order to switch differs across incumbents. For example, one firm's existing customer base may on average require high minimum bill savings in order to switch, while another firm has a customer base with on average low minimum bill savings required for switching. Since the differences across firms are small (see Table A in Appendix), we choose to work with a representative firm. 
TABLE 5 - CALCULATING THE PROFIT MAXIMISING PRICE DIFFERENTIAL FOR INCUMBENTS

\begin{tabular}{|c|c|c|c|c|c|}
\hline $\begin{array}{l}\text { Bill savings } \\
\text { per year in } \\
\text { euros }\end{array}$ & 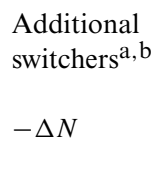 & $\begin{array}{l}\begin{array}{l}\text { Would } \\
\text { stay }{ }^{\mathrm{a}, \mathrm{b}}\end{array} \\
N+\Delta N\end{array}$ & $\begin{array}{l}\text { Gains from } \\
\text { raising price } \\
\bar{Q} \cdot(N+\Delta N) \\
\Delta P_{I}\end{array}$ & $\begin{array}{l}\text { Losses from } \\
\text { additional } \\
\text { switchers } \\
\bar{Q} \cdot\left(P_{I}-P_{E}\right) \cdot \\
\Delta N\end{array}$ & Net gains \\
\hline 25 & 18 & 982 & 24,550 & 0 & 24,550 \\
\hline 50 & 135 & 847 & 21,175 & 3,375 & 17,800 \\
\hline 75 & 161 & 686 & 17,150 & 8,050 & 9,100 \\
\hline 100 & 174 & 512 & 12,800 & 13,050 & -250 \\
\hline 150 & 188 & 324 & 16,200 & 18,800 & $-2,600$ \\
\hline 200 & 59 & 265 & 13,250 & 8,850 & 4,400 \\
\hline 250 & 56 & 210 & 10,500 & 11,200 & -700 \\
\hline 300 & 27 & 183 & 9,150 & 6,750 & 2,400 \\
\hline $300+$ & 35 & 148 & & & \\
\hline $\begin{array}{l}\text { Never \& sav- } \\
\text { ings play no } \\
\text { role }\end{array}$ & 148 & & & & \\
\hline Total & 1,000 & & & & \\
\hline
\end{tabular}

Notes:

${ }^{a}$ Post-stratified estimates are used (rounded to integers). The total is normalised to 1000. Since we have only discrete information on the distribution of the expected savings, we assume that consumers do not leave as long as the price change remains within the range defined by the two neighbouring values of expected savings. Additional switching occurs only when the price reaches the end of the range.

$\mathrm{b}$ The answers 'do not know' are treated as missing values.

Source: Direct computation from survey data, based on the methodology from Giulietti et al. (2005).

incumbents and new entrants of 25 euros on the annual energy bill, 18 of the firm's consumers would switch to a new entrant. Initially (before raising its price) the firm did not make a profit on these consumers (this follows from our assumption that new entrants charge at marginal cost). Therefore the loss in market share does not lead to a fall in profits. However, profits on remaining customers would increase by 25 euros per customer, or 24,550 euros in total. The next row repeats this calculation for a price differential of 50 euros. In this case, the additional profits from higher prices paid by remaining customers must be compared to the fall in profit due to consumers who switch to other providers. It turns out that at a price differential of 100 euros the loss in profit due to the decline in the number of customers outweighs the gain in 
profits on remaining customers. We conclude that the profit maximising price differential for an incumbent firm is somewhere between 75 and 100 euros. ${ }^{14}$

Interestingly, for the UK, Giulietti et al. (2005) obtain the threshold amount of 8 pounds per month (150 euros per year) - twice the amount in The Netherlands. Only $45 \%$ of the UK consumers would be willing to switch at this amount.

\subsection{Consumer Welfare After Liberalisation: Two Scenarios}

Since the price elasticity of the demand of small consumers for energy is small, price changes have little effect on demand. Therefore the effect of liberalisation of this market segment on total welfare (the sum of consumer and producer surplus) is small. ${ }^{15,16}$ The most important effect of liberalisation in this market segment is a reallocation of surplus between firms and consumers.

We assess potential effects of switching costs on surplus reallocation between firms and consumers under two scenarios, an optimistic one and a pessimistic one. In the optimistic scenario, we assume that switching costs fall in the years following liberalisation, so that the willingness to switch at a given price differential increases. This reduces the price differential between incumbents and entrants. In the pessimistic scenario, switching costs remain at the current level and the willingness to switch does not change. In such a case, it is profitable for incumbents to raise prices compared to the level just before liberalisation. For both scenarios we estimate the change in consumer welfare as a consequence of liberalisation. This change equals:

$$
\begin{aligned}
\text { Change in consumer welfare }= & \bar{Q} \cdot\left(P_{E}-P_{B}\right) \cdot S \\
& +\bar{Q} \cdot\left(P_{I}-P_{B}\right) \cdot N S,
\end{aligned}
$$

where $P_{B}$ is the price that would have been observed without liberalisation; $S$ the number of switchers and $N S$ is the number of non-switchers.

14 According to the press release of DTe of 3.12.2004, the actual gap between the cheapest and the most expensive energy provider observed at the end of 2004 was 150 euros for an average household. This is above the amount that we would expect on the basis of Table 5 . This difference may be due to the differences in distribution of potential savings across firms and possibly somewhat more cost-efficient operation of the cheapest new firms.

15 According to Baker et al. (1989), the price elasticity of residential demand for gas is -0.34 . 16 We ignore the cost of entry. Although entry is costly, these costs are sunk, and are unimportant in the long run. Giulietti et al. (2005) assumes entrants' initial cost to be 12.5 pounds (18 euros) per year per switcher. This cost will be recovered over the next years, which means that the prices will be a bit higher than it would be without such costs. However, allocated over several years, the effect on price is small. We do not consider the administrative cost of switching for the firms ether. This cost is minor. 
The first term on the right hand side of equation (5) represents the welfare gains of switchers, the second term the welfare gains or losses of nonswitchers.

For $P_{I}, S$ and $N S$ we will make scenario-specific assumptions as explained below. $P_{B}$, the price that would have applied in the counterfactual without liberalisation, is of course the same in both scenario's. In order to calculate $P_{B}$, we use the data in Table 5 (second column). These data show that $1.8 \%$ of all customers would switch for bill savings of 25 euros per year, and $15.3 \%$ would switch for bill savings of 50 euros per year. Linear interpolation implies that the amount of bill savings consistent with the $9 \%$ switching level in the data is around 40 euros per year. Hence, we assume this to be the difference between the price immediately before and the price of entrants immediately after liberalisation:

$$
P_{B}-P_{E}=40
$$

\subsubsection{Scenario-specific Assumptions}

In the optimistic scenario we assume that prices of incumbents equal prices of new entrants, which in turn equal marginal costs:

$$
P_{I}=P_{E}=C
$$

where $P_{E}, P_{I}$ and $C$ are defined as before. In this case, equation (5) reduces to

$$
\bar{Q} \cdot\left(P_{E}-P_{B}\right) \cdot(S+N S) .
$$

The number of switchers does not affect consumer welfare in this scenario.

In the pessimistic scenario the price differential between incumbents and entrants equals the profit maximising price differential calculated in the previous subsection: 75 euros or more. We shall assume that entrants price competitively, while the incumbents charge 75 euros above the entrants:

$$
P_{I}=P_{E}+75=C+75
$$

As shown in the previous section, this price differential maximises incumbents' profit. At this price differential, 31\% of all customers switch, while the rest stays with their incumbent supplier.

Note that we maintain the assumption of marginal-cost pricing by entrants. If entrants price above marginal cost, then the overall price level is higher than in the case of marginal-cost pricing by entrants. This would lead to a large loss of consumer welfare in the pessimistic scenario. 
TABLE 6 - WELFARE EFFECTS UNDER TWO SCENARIOS

\begin{tabular}{llc}
\hline Scenario & Optimistic & Pessimistic \\
\hline \% Consumers switched & Irrelevant & $31 \%$ \\
\% Consumers paying competitive price & $100 \%$ & $31 \%$ \\
& & mln euros \\
\cline { 2 - 3 } & \multicolumn{2}{c}{} \\
Transfer of welfare from firms to switchers & 25 & 87 \\
Transfer of welfare from firms to non-switchers & 280 & -169 \\
Total transfer from firms to consumers & & -82 \\
\hline
\end{tabular}

Source: Computations on the basis of survey data. The total number of Dutch households is about $7 \mathrm{mln}$. The transfer amounts for switchers (non-switchers) are computed as the product of the total number of switchers (non-switchers) and their respective price changes assumed in each scenario, e.g. the transfer to switchers in the optimistic scenario is equal to $7 \mathrm{mln} * 0.09 * 40$.

\subsubsection{Results}

Table 6 shows the effects of liberalisation on consumer welfare for both scenarios. We distinguish between welfare effects for switchers and for nonswitchers.

In the optimistic scenario, both consumer groups benefit from price decreases and liberalisation brings large benefits in terms of welfare reallocation from firms to consumers. However, in the pessimistic scenario, where $31 \%$ switches while the rest stays with incumbents who raise prices 75 euros above entrants, the effect on consumer surplus is negative. Notice also that, if entrants indeed price competitively, 75 euros is on the lower boundary of possible estimates of the profitable price increase. If larger prices are profitable, then the consumer welfare loss in this scenario is also larger. For example, the consumer loss would be two times larger if the price gap would increase to 90 euros.

The results of these computations imply that while liberalisation is justified under the first scenario, it may result in consumer welfare loss under the second scenario. ${ }^{17}$ Under the pessimistic scenario, in which incumbents raise prices by 75 euros above the competitive level, consumers lose about $82 \mathrm{mln}$ euros compared to the initial situation. However, if incumbents follow entrants' prices, consumers would gain about $280 \mathrm{mln}$ euros.

One caveat is in order with respect to the above calculations. These calculations ignored effects from liberalisation other than price changes. In reality, liberalisation may also intensify quality competition which would bring extra benefits to consumers.

17 Here we focus on the effect of switching costs. Joskow and Tirole (2004) and Newbery (2002) present other arguments that may cast doubt on the effectiveness of competition in the small customer segment, e.g., an argument about the necessity to rely on load-profiling. 


\section{POLICIES TO REDUCE SWITCHING COSTS}

Policies that reduce search and switching costs may increase the probability that the market will evolve towards the optimistic scenario. In addition to reducing actual switching costs (e.g. switching fees), policy can aim at improving consumer perceptions of search and switching costs. ${ }^{18}$

\subsection{Reducing Switching Fees}

Switching fees are fees charged to customers for terminating contracts prematurely. Switching fees are only allowed for contracts with a fixed duration. In The Netherlands, DTe caps the maximum of such fees. ${ }^{19}$ Switching fees are not necessarily bad for welfare. First, they may reflect the actual administrative cost incurred by the firm when a customer switches to another supplier. Switching costs might then serve to discourage socially wasteful switching. Second, switching costs may play a crucial role in sustaining fixed price contracts. Without switching fees, such contracts would not be offered, or would be offered at much higher prices. For these reasons, a complete prohibtion of switching fees is not desirable.

In an emerging market where there are serious concenrns that switching costs may inhibit competition, a case could be made for not giving too much weight to the first argument. There is a presumption that the administrative costs of handling switching to the firm do not need to be high. Moreover, policy makers may rather incur a risk of setting the switching fees too low and accept some excess switching than to allow for switching fees and thus prevent competition.

With respect to the second argument, this does not apply to contracts with variable prices, where the price can be adjusted in accordance with market developments. For such contracts, switching fees do not serve an economically useful function. ${ }^{20}$ Switching fees are also not justified in the case of a silent extension of these contracts, as is current practice.

18 See Pomp et al (2005) for a further discussion of policies to reduce switching costs.

19 The maximum depends on the remaining time of the contract, but not on the type of contract (fixed/variable price). For 1-year contracts, the switching fee cannot exceed 50 euros. For contracts with a longer term, the maximum compensation is 25 euros per half a year of the remaining contract length. Additionally, a company can charge a customer up to 50 euros to compensate for the welcome present received by the customer upon signing the contract. In the case if a contract has been extended silently, a consumer who wants to interrupt such a contract can face a maximal fine of 25 euros. (DTe 2005.)

20 Frequent switching is, to some extent, also prevented by law, which allows a term of 30 days for ending a contract. (Article $95 \mathrm{~m} / 10$ of the Electricity Law.) 


\subsection{Reducing Choice Complexity}

Liberalisation has opened up a wide menu of options for consumers to choose from. Currently customers have to choose between fixed prices over 1,2 or 3 years or a variable price. Furthermore, there are 'budget', 'standard' or 'standard-plus' contracts and/or 'evening-active' and 'standard peaklow tariffs' (differentiating across different consumption patterns). The effect of such product differentiation on welfare is ambiguous. On the one hand, differentiation accommodates heterogeneity in consumer preferences. On the other hand, product differentiation may increase consumer switching costs, as it becomes more difficult to compare across firms and contracts. 'Light' forms of standardisation of contracts may be appropriate in this case. Norway represents an interesting example of such standardisation-'light'. In 1998, the Norwegian Competition Authority (NCA) began to publish comparative tables for standardised contract types on its website in order to help consumers to compare different contracts and suppliers. Firms could still offer other types of contracts, but these would not be included in the comparative tables of the NCA. For example, in 2003, Norwegian consumers could easily get an overview of spot prices, fixed price contracts lasting for 1 or 3 years, as well as the standard variable electricity price (Norwegian Competition Authority, 2003).

\subsection{Educating the Public}

Many consumers do not have any experience with switching in this market. They have to rely on information regarding other people's experiences. Given that the media is more likely to focus on negative experiences, companies' mistakes in handling switching create a negative externality, increasing perceived switching costs. Therefore, providing consumers with correct information, for example through advertising that all suppliers have the same reliability and that switching costs are actually low, may improve consumer perceptions.

\section{CONCLUSIONS}

Our analysis of consumer switching behaviour in Netherlands residential energy markets stresses the importance of switching costs. Consumers who think that searching and switching is difficult and time consuming may be less likely to switch to another provider. Given the observed distribution of (perceived) switching costs, it may be profitable for incumbents to raise prices at least 75 euros per year above entrants. If such a situation persists, Dutch households would, on balance, not gain from liberalisation. Therefore, we 
stress the need for policies that reduce switching costs and that reduce the discrepancy between actual and perceived search and switching costs.

\section{APPENDIX}

Table A compares the distributions of the expected minimum bill savings of the three largest incumbents to the distribution in the total sample. Although firm-specific data better reflect the situation per firm, the estimates for the total sample have smaller standard errors.

TABLE A - MINIMUM BILL SAVINGS REQUIRED FOR SWITCHING, COMPARISON ACROSS THE LARGEST INCUMBENT FIRMS

\begin{tabular}{lrrrr}
\hline & \multicolumn{1}{l}{ Firm 1 } & \multicolumn{1}{l}{ Firm 2 } & \multicolumn{1}{l}{ Firm 3 } & Total sample \\
\hline Less than 25 euros & $1.7(0.8)$ & $2.2(0.8)$ & $1.2(0.6)$ & $1.8(0.4)$ \\
25-50 euros & $9.2(1.9)$ & $7.4(1.5)$ & $11.0(1.7)$ & $11.1(0.9)$ \\
$50-75$ euros & $11.3(2.1)$ & $11.5(1.8)$ & $13.4(1.8)$ & $12.6(1.0)$ \\
$75-100$ euros & $13.9(2.2)$ & $16.4(2.1)$ & $17.2(2.0)$ & $15.4(1.1)$ \\
100-150 euros & $19.3(2.6)$ & $17.0(2.1)$ & $21.5(2.2)$ & $18.0(1.2)$ \\
150-200 euros & $5.5(1.5)$ & $5.0(1.2)$ & $3.5(1.0)$ & $4.6(0.6)$ \\
200-250 euros & $5.9(1.5)$ & $4.6(1.2)$ & $3.5(1.0)$ & $4.4(0.6)$ \\
250-300 euros & $4.2(1.3)$ & $2.5(0.9)$ & $1.2(0.6)$ & $2.2(0.4)$ \\
More than 300 euros & $4.6(1.4)$ & $3.7(1.1)$ & $2.6(0.9)$ & $3.2(0.5)$ \\
Savings play no role in & $2.5(1.0)$ & $5.6(1.3)$ & $5.2(1.2)$ & $4.6(0.6)$ \\
switching decision & $5.5(1.5)$ & $6.5(1.4)$ & $4.9(1.2)$ & $6.2(0.7)$ \\
Will never change, indepen- & & & & \\
dently of the amount to be & $16.4(2.4)$ & $17.6(2.1)$ & $14.8(1.9)$ & $15.8(1.1)$ \\
saved & & & & \\
Do not know & & & & \\
\end{tabular}

Notes: This table gives the respective percentages and their standard errors. The table is based on information on contracts in the electricity market.

\section{REFERENCES}

Baker, P., R. Blundell and J. Micklewright (1989), 'Modelling Household Expenditure Using Microdata,' Economic Journal, 99(297), pp. 720-738.

CBS (Central Bureau of Statistics) (2005), Duurzame energie in Nederland 2005, report.

Consumentenbond (2004), 1-Meting Liberalisering Energiemarkt, report.

DTe (2005), Beleidsregel Redelijke Opzegvergoedingen Vergunninghouders. 
DTe (2006), 'Een markt (z)onder spanning', Marktmonitor, ontwikkeling van de Nederlandse kleinverbruikersmarkt voor Elektriciteit en Gas, januari 2006-juni 2006.

Energiened, (2002) Energy in The Netherlands, Facts and figures, publication by The Federation of Energy Companies in the Netherlands, EnergieNed, The Netherlands.

Giulietti, M., C. Waddams Price and M. Waterson (2005), 'Consumer Choice and Competition Policy: A Study of UK Energy Markets,' Economic Journal, 115(506), pp. 949-969.

Joskow, P. and J. Tirole (2004), 'Retail Electricity Competition,' mimeo, MIT and IDEI.

Klemperer, P. (1995), 'Competition When Consumers have Switching Costs: An Overview with Applications to Industrial Organization, Macroeconomics, and International Trade,' The Review of Economic Studies, 62(4), pp. 515-539.

Mulder, M. and V. Shestalova (2006), 'Costs and Benefits of Vertical Separation of the Energy Distribution Industry: The Dutch Case,' Competition and Regulation in Network Industries, 1(2), pp. 197-230.

Newbery, D.M. (2002), 'Issues and Options for Restructuring Electricity Supply Industries,' University of Cambridge, CMI Working Paper 01.

Norwegian Competition Authority, (2003), Annual report 2003, Norwegian Competition Authority, Norway.

Pomp, M., V. Shestalova, and L. Rangel (2005), 'Switch on the Competition: Causes, Consequences and Policy Implications of Consumer Switching Costs,' CPB Document 97.

Rice, J.A. (1995), Mathematical Statistics and Data Analysis, 2nd edn., International Thompson Publishing.

TenneT, (2006), Transportbalans 2006, publication by TennneT TSO B.V., The Netherlands.

Waterson, M. (2003), 'The Role of Consumers in Competition and Competition Policy,' International Journal of Industrial Organisation, 21(2), pp. 129-150. 